\title{
Modern Labor in Queensland: Its Rise and Failings, 1978-98
}

\section{Bradley Bowden*}

This article explores the emergence of "modern Labor" in Queensland. Previously under Trades Hall control, Queensland Labor was transformed in 1980 when the Reform Group gained control after intervention by Labor's Federal Executive. Between 1989 and 2012 it was only out of office once (1996-98). Labor's restructure, however, brought neither rank-and-file involvement nor a substantial membership. Authority was vested in factional powerbrokers. Whereas prior to 1980 Queensland Labor was a union-controlled party (ie a labour party), it now became a faction-controlled party.

As the second decade of the third millennium opened the Australian Labor Party (ALP) confronted deteriorating fortunes, having been ousted from office in Western Australia (2008), Victoria (2010), New South Wales (2011), the Northern Territory (2012) and Queensland (2012). In 2010 it lost its federal majority, surviving on the grace of rural Independents. Then, in losing federal office in September 2013 under a resurrected Kevin Rudd, Labor saw its primary vote fall to 34 per cent. This was a lower vote than that obtained in any post-war Commonwealth election. It was also worse than that secured by Labor candidates when Scullin was evicted from power in 1932, when 37.7 per cent of the electorate voted Labor. ${ }^{1}$ An internal Labor review, conducted after the 2010 federal result, concluded that "structurally" the party was "in decline." In the eight years to 2010 the party lost 20 per cent of its national membership, leaving approximately 38,000 ticket holders. By contrast, Labor had 150,000 members in the 1930s. Those retaining their membership, the 2010 review observed, "feel alienated and disenfranchised in the modern Labor Party." ${ }^{3}$ The view that Labor is facing an organisational crisis is one reinforced in a plethora of recent books and articles. ${ }^{4}$ Foremost among these is the work of Rodney Cavalier, who argues that modern Labor is controlled by a "political class" of self-interested

* The author would like to thank the two anonymous referees of Labour History for their comments and suggestions.

1. The 1932 vote was, admittedly, divided between "official" Labor and "Lang" Labor in NSW.

2. Steve Bracks, John Faulkner and Bob Carr, 2010 National Review: Report to the ALP National Executive (Canberra: ALP National Secretariat, 2010), 11, 9.

3. Bracks, Faulkner and Carr, 2010 National Review, 10-11. (Note: on p, 13 the Review indicates 45,000 members, but the Table on p. 10 suggests 38,000 members.) See also, Troy Bramston, "Troglodyte Club Refuses to Reform," Australian, 5 December 2011, 12.

4. These include, David Clune and Rodney Smith, ed, From Carr to Keneally: Labor in Office in NSW 1995-2011 (Sydney: Allen \& Unwin, 2012); Simon Benson, Betrayal: The Lnderbelly of Australian Labor (Sydney: Pantera Press, 2010); Troy Bramston, Looking for the Light on the Hill; Modern Labor's Challenges (Melbourne: Scribe Publications, 2011); Maxine McKew, Tales from the Political Trenches (Melbourne: Melbourne University Press, 2012); Lindsay Tanner, Politics with Purpose (Melbourne: Melbourne University Press, 2012); Frank Sartor, Fog on the Hill: How NSW Labor Lost its Way (Melboume: Melbourne University Press, 2011); David Marr, "The Political Journey of Kevin Rudd," Quarterly Essay 38 (June 2010); Tom Bramble and Rick Kuhn, Labor's Conflict: Big Business, Workers and the Politics of Class (Melbourne: Cambridge University Press, 2011); Bradley Bowden, "From Defeat to Catastrophe: The Labor Party in Rural New South Wales, 1988-2011," Labour History, no. 103 (November 2011): 227-46. 
apparatchiks. ${ }^{5}$ Nick Dyrenfurth and Tim Soutphommasane similarly conclude that "Nihilistic apparatchiks direct the affairs of the party." 6 What, however, is really new in all this? Labor has, after all, previously had long periods when electoral success eluded it. Membership "disenfranchisement" is also not new. As Michael Hogan noted in his history of Labor in inner-city Glebe, "from the beginning ... the organisation of the Labor Party was elitist. ${ }^{\prime 7}$ Even the presence of middle-class elements in Labor's ranks is hardly new. As Vere Gordon Childe noted in 1923, "middle-class voters" frequently dominated Labor's Leagues (Branches). ${ }^{8}$

Although there are parallels between Labor's past and present problems, this article argues that the current crisis is different because "modern Labor" is different, and that if we are to properly understand Labor's current woes we need to first comprehend the historical process that gave rise to "modern Labor" after 1970. While the outcomes of this transformation are well described by Cavalier and others - a reliance on media campaigns rather than local activists and a domination of internal life by factional warlords - the historic process that brought about this transformation is surprisingly poorly recorded. To the extent that it is recorded, the circumstances in Labor's Victorian Branch have attracted most attention. Here, as studies by Frank Bongiorno, Paul Strangio and others note, a predominately middle-class reform group - the "Participants" - wrenched power from a Trades Hall-dominated Left faction in $1970 .{ }^{9}$ Such accounts, however, largely restrict themselves to the events surrounding federal Labor's intervention into Victorian affairs. While Strangio notes that "institutionalised factions" was one result of this, ${ }^{10}$ few other links are drawn between this reform era and Labor's current problems.

In exploring the roots of "modern Labor," this study focuses on Queensland Labor between 1978 and 1998. Here, as in Victoria, intervention by Labor's Federal Executive favoured a largely middle-class "Reform Group," leading to profound changes in the party's structure and trajectory. Despite the growing importance of Queensland and Queenslanders (most notably Kevin Rudd and Wayne Swan) in Labor's travails, this process of change has been poorly recorded. Other than Fitzgerald and Thornton's Labor in Queensland (completed in 1988), there are no major studies of Queensland Labor since 1957.11 The three accounts of the reform era that preceded the Goss government's election in 1989 are the work of Labor luminaries

5. Rodney Cavalier, Power Crisis: The Self-Destruction of a State Labor Party (Melbourne: Cambridge University Press, 2010); Rodney Cavalier, "Could Chifley Win Labor Preselection Today?," in Coming to the Party: Where to Next for Labor?, ed. Barry Jones (Melboume: Melbourne University Press, 2006), 57-65; Rodney Cavalier, "The Labor Party," in Clune and Smith, From Carr to Keneally,
3-14.

6. Nick Dyrenfurth and Tim Soutphommasane, "Postscript," in All that's Left: What Labor Should Stand For, ed. Nick Dyrenfurth and Tim Soutphommasane (Melbourne; Australian Scholarly Publishing, 2010), 209.

7. Michael Hogan, Local Labor: A History of the Labor Party in Glebe 1891-2003 (Sydney: Federation Press, 2004), 212.

8. Vere Gordon Childe, How Labour Governs (Melbourne: Melbourne University Press, 1963), 20. Frank Bongiorno, "Remembering Ol' 55: The Victorian Fabian Society and the Road to Intervention," in The Great Labor Schism: A Retrospective, ed. Brian Costar, Peter Love and Paul Strangio (Melbourne: Scribe, 2005), 324 39; Paul Strangio, "Closing the Split: Before and After Federal Intervention in the Victorian ALP," in Costar, Love and Strangio, The Great Labor Schism,

10. Strangio, "Closing the Split," 356.

11. Ross Fitzgerald and Harold Thornton, Labor in Queensland: From the 1880s to 1988 (Brisbane: University of Queensland Press, 1989). 
(two by Peter Beattie and one by Wayne Swan)..$^{12}$ None draws links between this era and Labor's subsequent problems. In researching the experiences of modern Labor in Queensland this study is the first to draw upon the state party's records for the 1980s and 1990s; records deposited (though not yet catalogued) in Brisbane's John Oxley Library. It concludes that while modern Labor in Queensland after 1980 was characterised by many things - the substitution of money for members, affirmative action and proportional representation of factions - the central change was the replacement of a union-controlled party (ie a labour party) by a factioncontrolled party. Within this new entity the factions exploited control of the union vote as one means of exercising power but were increasingly dominated by the professional middle class. This outcome reflected the fact that, organisationally, modern Queensland Labor became trapped between its past and changed social circumstances. In a society in which ever fewer voters were unionists, Labor's factional system, which drew on its unionised past, prohibited a mass membership. Conversely, the changed nature of society, and the increasing middle-class orientation of its leadership, ruled out revitalisation as a "labour" organisation.

\section{Conceptualising "Modern Labor"}

Until the last decade or so, most Labor Party histories fell within one of two broad narratives. ${ }^{13}$ The first of these detects the mark of Cain on Labor. "There is a fundamental continuity in the history of the ALP from the 1880 s to the first decade of the twenty-first century," so Bramble and Kuhn observe. If Labor draws worker support its behaviour is nevertheless shaped by "its relationship with the capitalist class, which it serves. ${ }^{14}$ While this Marxist view has a long heritage, ${ }^{15}$ it has been supplemented by those who believe that Labor fell from grace during the 1980s when it embraced the free market. ${ }^{16} \mathrm{New}$ Left historians have also criticised Labor for entrenching privilege based on ethnicity and gender. ${ }^{17}$ At odds with this critical narrative are accounts that portray Labor as an agent of positive social change. Originally the preserve of activists such as W. G. Spence, ${ }^{18}$ this approach was subsequently taken up by liberal historians, most notably Keith Hancock, before

12. Peter Beattie, In the Arena: Memoirs of an ALP State Secretary (Brisbane: Boolarong, 1990); Peter Beattie, Making a Difference (Sydney: HarperCollins, Sydney, 2005); Wayne Swan, "The Labor Party," in Political Crossroads: The 1989 Queensland Election, ed. Rosemary Whip and Colin Hughes (Brisbane: University of Queensland Press, 1991), 96-112.

13. The Labor literature is best reviewed in, Nick Dyrenfurth, "Labour and Politics," Labour History, no. 100 (November 2011): 105-26.

14. Bramble and Kuhn, Labor's Conflict, 24 .

15. The most significant Marxist accounts are: Robin Gollan, Radical and Working Class Politics: $A$ Study of Eastern Australia 1850-1910 (Melbourne: Melbourne University Press, 1960); Ian Turner, Industrial Labour and Politics: The Dymamics of the Labour Movement in Eastern Australia, 1900-1920 (Sydney: Hale \& Iremonger, 1979); Verity Burgmann, "In Our Time": Socialism and the Rise of Labor, 1885-1905 (Sydney: George Allen \& Unwin, 1985).

16. Peter Beilharz, Transforming Labor: Labour Tradition and the Labor Decade in Australia (Melbourne: Cambridge University Press, 1994); Graham Maddox, The Hawke Government and the Labor Tradition (Melbourne: Penguin, 1989); Andrew Scott, Fading Loyalties: The Australian Labor Party and the Working Class (Leichhardt: Pluto Press, 1991).

17. Humphrey McQueen, A New Britamia (Melbourne: Penguin, 1970); Ann Curthoys and Andrew Markus, ed., Who are Ow Enemies? Racism and the Working Class in Australia (Sydney: Hale \& Iremonger, 1978); R. W. McConnell and T. H. Irving, Class Structure in Australian History (Melbourne: Longman Cheshire, 1980).

18. John Norton, ed., The History of Capital and Labour in All Lands and Ages (Sydney: Oceanic Publishing, 1888); George Black, Labor in Politics: The New South Wales Labor Party (Sydney: Workman, 1894); William Spence, Australia's Awakening (Sydney: Worker Trustees, 1909). 
reaching its epiphany in the "labourist" tradition exemplified by Nairn, Murphy and Hagan. ${ }^{19} \mathrm{~A}$ common thread that unites this second narrative is the belief that Labor always reached beyond its union base. As Hancock observed in 1930, even though Labor was "a product of trade unionism," to be successful it had to "win the suffrages of" other groups. ${ }^{20}$ It was this that made Labor more than a representative of sectional interest. More recently, John Rickard, Bruce Scates, Frank Bongiorno and Nick Dyrenfurth have emphasised how Labor drew on a variety of radical traditions, not just those grounded in unionism. ${ }^{21}$

While the narratives identified above are valuable in understanding Labor's past, their usefulness for understanding "modern Labor" is less clear. Indeed, while reference to "modern Labor" now abounds there has been no attempt to systematically define what the term actually means. Nor have we seen detailed accounts of when and how "modern Labor" emerged from "Old Labour." The best descriptions of modern Labor's features are found in a new critical narrative that is largely the work of senior party elders - Rodney Cavalier, Barry Jones, John Button and John Faulkner - disillusioned with the party of their autumn years. ${ }^{22}$ Cavalier's work sees the fullest development of this narrative. In his account, Labor's transformation resulted from "the emergence of a political class" of university-trained apparatchiks "in the 1980s." Having been appointed to positions in the declining union movement, they then used the unions to "take-over" the Labor Party. ${ }^{23}$ Cavalier also suggests, with merit, that: "Modern Labor operates in accordance with an axiom: a parliamentary Leader sustained by good opinion polls will prevail in all matters, including decisions contrary to party policy." ${ }^{24}$ Such descriptions, however, leave open some important questions. What institutional barriers remain with Labor to restrict the rise of "Bonpartist" figures who would use their popularity to reshape Labor for their own ends? Even more poignantly is the question of residual "union control" of Labor. Is such "control" still meaningful or have unions become, as Cavalier implies, simply a device through which a new elite exercises power.

In conceptualising the nature of "modern Labor" it is useful to return to Robert Michels' classic, Political Parties. While Michels is best known for his postulation about the "iron law of oligarchy," he also provided insights into power struggles within political parties, noting: "Very rarely does the struggle between old leaders

19. Keith Hancock, Australia (London: Ernest Benn, 1930); Bede Nairn, Civilising Capitalism: The Beginnings of the Australian Labor Party (Melbourne: Melbourne University Press, 1973); D. J. Murphy, R. B. Joyce and Colin Hughes, ed., Prelude to Power: The Rise of the Labour Party in Queensland 1885-1915 (Brisbane: Jacaranda Press, 1970); D. J. Murphy, ed., Labor in Politics: The State Labor Parties in Australia 1880-1920 (Brisbane: University of Queensland Press, 1975); Jim Hagan and Ken Turner, A History of the Labor Party in New South Wales 1891-1991 (Melbourne: Longman Cheshire, 1991).

20. Hancock, Australia, 198

21. John Rickard, Class and Politics: New South Wales, Victoria ond the Early Commonwealth, 1890-1910 (Canberra: ANU Press, 1976); Bruce Scates, A New Australia: Citizenship, Radicalism and the First Republic (Melbourne: Cambridge University Press, 1997); Frank Bongiorno, The People's Party: Victorian Labor and the Radical Tradition, 1875-1914 (Melbourne: Melbourne University Press, 1996); Nick Dyrenfurth, Heroes and Villains: The Rise and Fall of the Early Labor Party (Melbourne: Australian Scholarly Publishing, 2011).

22. Barry Jones, "Where are We Coming From," in Jones, Coming to the Party, 3-28; John Button, "Beyond Belief: What Future for Labor?," in Jones, Coming to the Party, 47-56; John Faulkner, "Apathy and Anger," in Jones, Coming to the Party, 66-78; Cavalier, "The Labor Party," 3-14; Cavalier, Power Crisis; Cavalier, "Could Chifley Win," 57-65.

23. Cavalier, Power Crisis, 51-52.

24. Cavalier, Power Crisis, 184. 
and the new end in a complete defeat of the former." Instead, "typically," the party finds itself governed by "an amalgam ... of the two elements." ${ }^{25}$ This formulation has application to the circumstances that gave rise to "modern Labor." By common consent, the process of transformation that led to what is called "modern Labor" began around 1970, when Labor successfully reached out to the growing professional middle class. In Paul Kelly's much cited opinion: "Gough Whitlam is the founder of the modern Labor Party ... Whitlam fused Labor into a party resting upon [both] working class and middle class votes." ${ }^{26}$ Dyrenfurth similarly observes that: "Since Whitlam's 1960s party reforms, Labor's membership is likely to be dominated by middle-class activists." ${ }^{27}$ Such conclusions almost certainly exaggerate Whitlam's role in Labor's transformation. A series of articles by Labor insiders, written in the aftermath of Labor's 1972 federal victory, suggest that even at this stage a centralised marketing machine, largely funded by business, underpinned success. ${ }^{28}$ Nevertheless, the sociological change within both Labor and the wider society was real enough. The problem was, as Labor's 2010 National Review noted: "Labor's structures and practices are largely drawn from the time of the Party's formation 120 years ago. ${ }^{29}$

With Labor again in crisis it is not surprising for calls to emerge advocating a replication of earlier reform eras. Dyrenfurth and Soutphommasane, for example, observe that: "If the [current] machine isn't willing, rank-and-file members must be brave enough to follow the example of Victorian Labor during the 1960s, " when "a dissident internal grouping" championed party modernisation. ${ }^{30}$ This study, however, in exploring Queensland's internal reform and their effects, suggests that while the reforms of the 1970s and 1980s assisted in the election of the Goss (1989-96), Beattie (1998-2007) and Bligh (2007-12) governments, they also created a faction-dominated party in the stead of the earlier union-controlled organisation.

\section{Queensland Labor in the 1960s and 1970s}

In the first half of the twentieth century, Queensland Labor differed from Labor elsewhere because Queensland was different. Whereas, nationally, employment in manufacturing easily surpassed that in farming in 1921, in Queensland the agricultural sector was the largest employer until 1954. Even at this latter date manufacturing employment in Queensland exceeded that in agriculture by the barest of margins with 20.6 per cent of the workforce engaged in the former and 20.4 per cent in the latter. Nationally, at this time, manufacturing and agriculture employed 27.8 per cent and 13.3 per cent respectively. ${ }^{31}$ The long dominance of agricultural employment in the north meant that Queensland Labor became, as Brian Costar

25. Robert Michels, Political Parties: A Sociological Study of the Oligarchical Tendencies of Modern Democracy (Gloucester, Mass.: Peter Smith, 1978), 52.

26. Paul Kelly, The End of Certainty: Power, Politics and Business in Australia (Sydney: Allen \& Unwin, 2008), 20-21.

27. Nick Dyrenfurth, "It's the Culture, Stupid," in Dyrenfurth and Soutphommasane, All that's Left, 26

28. In particular, Vicky Braund, "Timely Vibrations: Labor's Marketing Campaign," in Labor to Power: Australia's 1972 Election, ed. Henry Mayer (Sydney: Angus \& Robertson, 1973), 18-28; Neal Blewett, "Labor 1968-1972: Planning for Victory," in Mayer, Labor to Power, 6-16.

29. Bracks, Faulkner and Carr, 2010 National Review, 9.

30. Dyrenfurth and Soutphommasane, "Postscript," 210.

31. Bradley Bowden, Simon Blackwood, Cath Rafferty and Cameron Allan, ed., Work \& Strife in Paradise: The History of Labour Relations in Queensland 1859-2009 (Sydney: Federation Press, 2009), 304-5. 


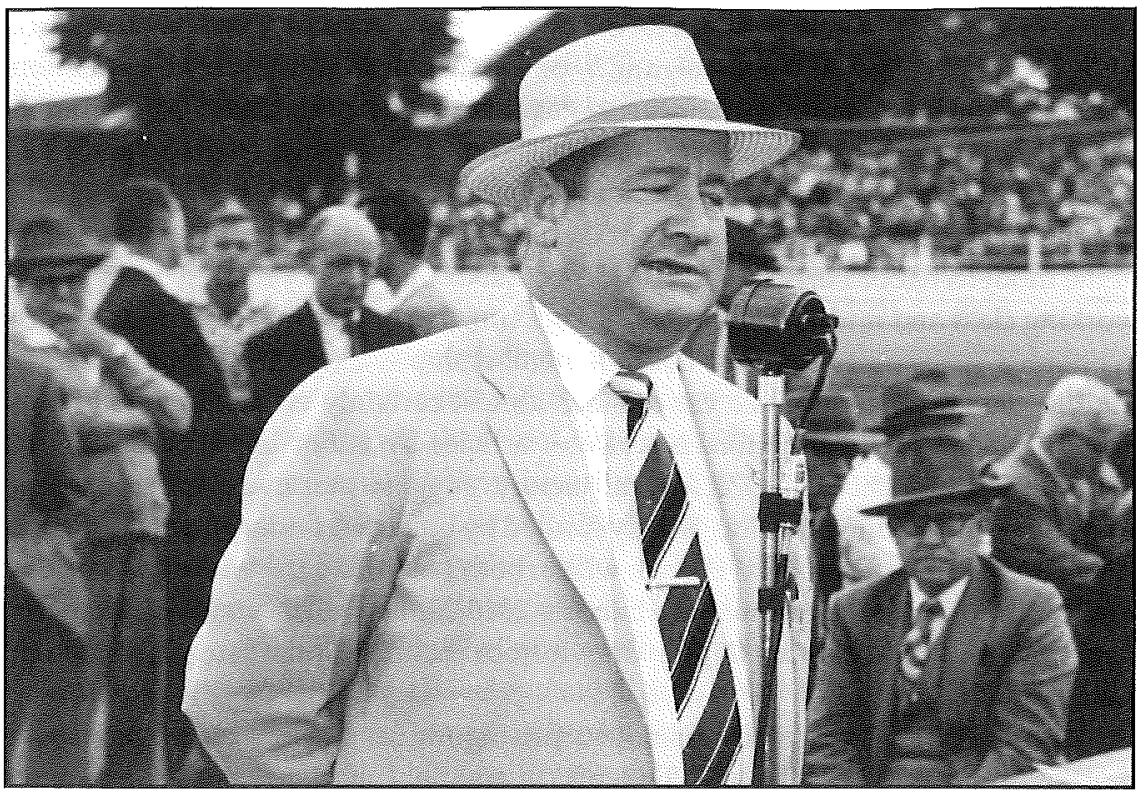

Figure 1: Jack Egerton Addressing a Stop-Work Meeting

A former boilermaker, Egerton served as Queensland Trades and Labour Council President, 1967-76 and as President of the Labor Party's Queensland Branch, 1968-76. He ruled both with an iron hand Courtesy: Queensland Trades and Labour Council Collection, Fryer Library, University of Queensland

has observed, "as much an agrarian party as it was a labour party." ${ }^{\prime 32}$ Power centred not on the metropolitan unions but on the rurally-oriented Australian Workers Union (AWU). The apogee of AWU power came under Clarrie Fallon, who served as its State Secretary from 1932 to 1950. Under Fallon, there were few government Ministers who did not owe their jobs to the AWU. ${ }^{33}$ Following Fallon's death in 1950, however, AWU dominance unravelled. Agricultural employment declined as machines replaced people. Political developments also undercut AWU power: Allying with future Queensland Trades and Labour Council's President, Jack Egerton, the AWU played a seminal role in expelling Labor's Premier, Vince Gair, in 1957. However, after Labor lost office in the ensuing election the AWU was increasingly isolated. In 1959 it effectively conceded power over Queensland Labor to Egerton and his Trades Hall supporters by disaffiliating. It did not rejoin Labor until 1978.

After the AWU's disaffiliation the Queensland Branch became something it had never previously been: an organisation of the urban blue-collar working class. With the AWU evicted, control of Labor was vested in the Trades Hall Affiliated Unions Committee. This body decided a seven-person Inner Executive which ran Labor with an iron hand. Even decisions involving Labor's considerable assets, which included radio $4 \mathrm{KQ}$ and the Branch's Breakfast Creek headquarters, were made without

32. Brian Costar, "For the Love of Christ, Mick, Don't Hit Him," in Costar, Love and Strangio, The Great Labor Schism, 62.

33. Mark Hearn and Harry Knowles, One Big Union: A History of the Australian Workers Union 18861994 (Sydney: Federation Press, 1996), 250-51. 


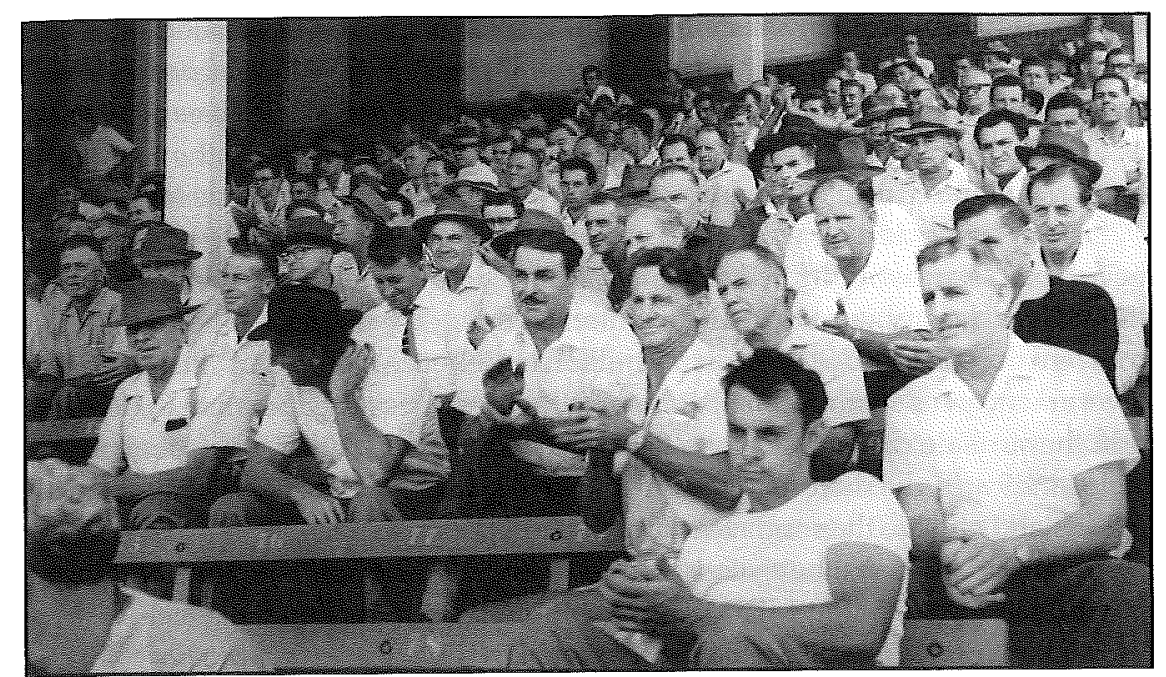

Figure 2: Stop-Work Meeting at Brisbane's Exhibition Ground, 1959

Under the leadership of Queensland Trades and Labour Council President, Jack Egerton, the Queensland Labor Party became something it had never before been - a representative of the unionised urban working class, Industrially militant, Trades Hall had little sympathy for the new social movements that emerged in the 1960 s

Courtesy: Queensland Trades and Labour Council Collection, Fryer Library, University of Queensland

reference to Labor's nominal ruling body, the Queensland Central Executive. ${ }^{34}$ Trades Hall control was ensured by giving members of affiliated unions the right to vote in pre-selections, even when they did not belong to the Labor Party. While other state Labor Branches abandoned this practice, in Queensland it persisted until federal intervention in 1980. Prior to this certain unions, most notably the Electrical Trades Union (ETU) under Neil Kane, became expert at exploiting this provision. Before pre-selections, blank "certificate books," which entitled each bearer to a vote, were given to trusted officials who used them to ensure the victory of favoured candidates. In 1977, seven of the 23 members of state caucus, including three once or future leaders (Jack Houston, Tom Burns and Kev Warburton) owed their seats to the ETU. ${ }^{35}$

Successful though Trades Hall was in controlling Labor, it was the product of a closed male world wherein entry into better paid blue-collar jobs, such as in the maritime industry or the wool stores, depended on one's union connections (the author obtained such a job in this way in the late 1970s). The idea that women would pursue a career was alien. As a Socialist Left pamphlet observed in 1980, the Trades Hall machine reflected "the most backward attitudes of ... the working class in regards to women's rights, youth rights, black rights." Those loyal to the machine were "comrades." Any who opposed it were "grubs. ${ }^{\prime 36}$ Such characteristics restricted Labor's appeal to an urban, blue-collar constituency. Unfortunately for Trades Hall,

34. Denis Murphy, Address to Labor Members: Bardon RSL, 5 February 1978, series OMEQ/62/57, Box 2624, John Oxley Library (hereafter JOL), Brisbane.

35. Centre Caucus, Submission to the ALP National Executive on the Queensland ALP, circa November 1979, series OMEQ/62/57, Box 2721, JOL, 8.

36. Socialist Left, "What Now? Socialist Left View," c. 1980, series 2657, Terry Hampson file, JOL, 1. 
by 1970 this constituency was shrinking rapidly. Whereas the percentage of the workforce engaged in largely urban blue-collar pursuits (utilities, manufacturing, construction and transport) remained constant at 38-39 per cent between 1954 and 1966 , by 1981 only 28.3 per cent were so engaged. The percentage of the workforce that was unionised also fell by 21 percentage points to 54 per cent between 1960 and $1970{ }^{37}$ Queensland Labor was also troubled by the fact that, not only were citizens in the northern state working in different jobs, they were also residing in new locations. Many were even new to the state as interstate migration swelled the population from two million in 1976 to almost 3.4 million in 1996. Most settled in either the local government areas surrounding Brisbane, where land was cheaper than in the City, or in the surfside municipalities to Brisbane's north and south. In consequence, as Table 1 indicates, the share of the population living in either Brisbane City or regional Queensland outside the southeast corner fell markedly after 1976. In Brisbane City, the population fell absolutely between 1976 and 1981 . When a rebound occurred growth still lagged behind that in the metropolitan fringe; an area which - using the Census criteria for the Brisbane Statistical Division (excluding Brisbane City) included Ipswich, Logan and Caboolture. Even faster growth was recorded in the southern coastal strip which, statistically, was counted as Moreton and Wide Bay. In 1996 this area, which included the Gold Coast, the Sunshine Coast and Hervey Bay, housed 871,378 - a total exceeding that for Brisbane City $(806,746){ }^{38}$

Table 1: Queensland Population, 1976-98

\begin{tabular}{|l|c|c|c|c|c|}
\hline & 1976 & 1981 & $\mathbf{1 9 8 6}$ & 1991 & 1996 \\
\hline \multirow{2}{*}{ Brisbane City } & 696,740 & 689,378 & 705,755 & 751,115 & 806,746 \\
& $(34 \%)$ & $(30 \%)$ & $(27 \%)$ & $(25 \%)$ & $(24 \%)$ \\
\hline \multirow{2}{*}{ Outer Metropolitan } & 261,005 & 339,149 & 443,646 & 582,983 & 642,137 \\
& $(13 \%)$ & $(15 \%)$ & $(17 \%)$ & $(20 \%)$ & $(19 \%)$ \\
\hline \multirow{2}{*}{ Southern Coastal } & 327,148 & 447,651 & 526,508 & 688,693 & 871,378 \\
& $(16 \%)$ & $(19 \%)$ & $(20 \%)$ & $(23 \%)$ & $(25 \%)$ \\
\hline \multirow{2}{*}{ Rural and Regional* } & 752,304 & 818,945 & 911,406 & 955,019 & $1,048,569$ \\
& $(37 \%)$ & $(36 \%)$ & $(35 \%)$ & $(32 \%)$ & $(31 \%)$ \\
\hline Total & $\mathbf{2 , 0 3 7 , 1 9 7}$ & $\mathbf{2 , 2 9 5 , 1 2 3}$ & $\mathbf{2 , 5 8 7 , 3 1 5}$ & $\mathbf{2 , 9 7 7 , 8 1 0}$ & $\mathbf{3 , 3 6 8 , 8 3 0}$ \\
\hline
\end{tabular}

Note: Percentages in parentheses; rounded to whole numbers.

* Excludes Moreton and Wide Bay Statistical Divisions.

Source: Australian Bureau of Statistics (ABS), Census: Historical Data, 1976-96, accessed September 2013,

$\mathrm{http}: /$ www.abs.gov.au/websitedbs/censushome.nsf/home/historicaldata?opendocument \&navpos $=280$

As a disconnect emerged between the orientation of Queensland Labor and the wider society the Branch found itself, almost everywhere, a minority force (see Table 2). In Brisbane, where it won ten seats in both 1977 and 1980, its vote was confined to older working-class electorates (South Brisbane, Wynnum and the like). In the metropolitan fringe two of its four successes were in Ipswich, then a mining and railway habitat. Labor's regional success was largely confined to the

37. Bowden et al., Work \& Strife in Paradise, 299-300, 305.

38. Compiled from Australian Bureau of Statistics (ABS), Census: Historical Data, 1976-96, accessed September 2013 http:/ / www.abs.govau/websitedbs/censushome.nsf/home/ historicaldata?opendocument\&navpos $=280$. 
larger provincial towns such as Bundaberg, Rockhampton, Mackay, Townsville and Cairns. Changing demographics also caused concern for the alliance of the two main Centre-Right parties known as the Coalition. To increase its urban appeal, the Country Party in 1974 rebadged itself as the National-Country Party, before adopting the title of the National Party in 1982. Under the direction of conservative populist, Joh Bjelke-Petersen (Premier, 1968-87), the Nationals launched concerted recruitment and electoral campaigns in Queensland's urbanised south-east. The initial fruits of this strategy were obtained in the south-east's once rural coastal or near coastal electorates. Of eight such electorates in 1980 the Nationals claimed seven (Surfers Paradise, Southport, South Coast, Cooroora, Landsborough, Gympie and Barambah). Only Maryborough was Labor held. As the Nationals encroached on Liberal bailiwicks a breach occurred in the Coalition, causing the Liberals to fight the 1983 election as a stand-alone force. Disaster ensued. The Liberal vote fell from 27 per cent in 1980 to 15 per cent. The Nationals won five Brisbane seats and an equal number of Outer Metropolitan electorates. This Coalition split also saw Labor increase its representation by seven to 32 . However, its primary vote rose by only three per cent (see Table 2). ${ }^{39}$ Partly, this failing reflected a low membership. In 1989, despite being reduced to a rump, the Liberals boasted 14,200 members. The Nationals claimed $50,000 .{ }^{40}$ Labor had 6,357.

Table 2: Distribution of Labor Seats, 1977-98

\begin{tabular}{|l|c|c|c|c|c|c|c|c|}
\hline & 1977 & 1980 & 1983 & 1986 & 1989 & 1992 & 1995 & 1998 \\
\hline Brisbane & 10 & 10 & 15 & 12 & 21 & 23 & 19 & 23 \\
$(27)$ & $(27)$ & $(27)$ & $(26)$ & $(26)$ & $(27)$ & $(27)$ & $(27)$ \\
\hline Outer Metropolitan & 4 & 4 & 5 & 7 & 11 & 14 & 12 & 10 \\
& $(10)$ & $(10)$ & $(10)$ & $(11)$ & $(11)$ & $(14)$ & $(14)$ & $(14)$ \\
\hline Southern Coastai & 1 & 1 & 0 & 0 & 3 & 3 & 3 & 1 \\
& $(8)$ & $(8)$ & $(8)$ & $(12)$ & $(12)$ & $(16)$ & $(16)$ & $(16)$ \\
\hline Rural and Regional & 8 & 10 & 12 & 11 & 19 & 14 & $11^{\ddagger}$ & $10^{\ddagger}$ \\
& $(37)$ & $(37)$ & $(37)$ & $(40)$ & $(40)$ & $(32)$ & $(32)$ & $(32)$ \\
\hline Total Labor & 23 & 25 & 32 & 30 & 54 & 54 & $45^{\ddagger}$ & $44^{\ddagger}$ \\
\hline Total Seats & 82 & 82 & 82 & 89 & 89 & 89 & 89 & 89 \\
\hline Primary Vote & $43 \%$ & $41 \%$ & $44 \%$ & $41 \%$ & $50 \%$ & $49 \%$ & $43 \%$ & $39 \%$ \\
\hline
\end{tabular}

Note: Total for each category in parentheses.

* Corresponds to Moreton and Wide Bay census districts.

† Liberals win Mundingburra, 1996 † pro-Labor Independent in Nicklin

Source: ABC News, Antony Green's Electoral Publication Archive, accessed September 2013

www.abc.net.au/elections/archive/\#qld

\section{Reform, 1978-89}

If in the 1970s Labor relied on the blue-collar vote, few industrial workers were members. Moreover, as Table 3 indicates, by 1976 membership was well below

39. Unless otherwise stated, the electoral statistics cited in this article are drawn from ABC News, Antony Green's Electoral Publication Archive, accessed September 2013, www.abc.net.au/elections/ archive/\#qld.

40. Australian, 7-8 May 1988, 8. 
Labor's peak strength of 11,139, obtained in 1938.41 The heaviest losses were felt in strongholds where blue-collar jobs were disappearing. By 1981 Ipswich, a long-time mining and railway hub, had only 23 members. Rockhampton had 42. By contrast, branches in Brisbane's middle-class electorates flourished. Toowong, adjacent the University of Queensland, had 123 members, more than any other. The Gap had 100 members. Other prospering branches in trendy locales included Fortitude Valley (57), Indooroopilly (44) and Paddington (31)..$^{42}$ Increasingly, this membership found itself at odds with Trades Hall.

Table 3: Queensland Labor Membership, 1976-98

\begin{tabular}{|c|c|}
\hline Year & Membership \\
\hline 1976 & 6890 \\
\hline 1977 & NA \\
\hline 1978 & 6618 \\
\hline 1979 & 6570 \\
\hline 1980 & 6171 \\
\hline 1981 & 6596 \\
\hline 1982 & 6776 \\
\hline 1983 & 7623 \\
\hline 1984 & 8086 \\
\hline 1985 & 7817 \\
\hline 1986 & 7756 \\
\hline 1987 & 7578 \\
\hline
\end{tabular}

\begin{tabular}{|c|c|}
\hline Year & Membership \\
\hline 1988 & 7125 \\
\hline 1989 & 6367 \\
\hline 1990 & 7169 \\
\hline 1991 & 7213 \\
\hline 1992 & 7246 \\
\hline 1993 & NA \\
\hline 1994 & 7492 \\
\hline 1995 & 6800 \\
\hline 1996 & 6800 \\
\hline 1997 & NA \\
\hline 1998 & 7937 \\
\hline
\end{tabular}

Source: State Secretary Reports, 1978-9843

On 5 February 1978 a challenge to Labor's old guard was formally launched in fashionable Bardon when Denis Murphy and Peter Beattie addressed 500 party faithful, obtaining endorsement for the establishment of the "Reform Group." This challenge had sprung from a barbecue at Beattie's house on 11 December the previous year when, as one press account recalled, " 82 concerned, middle-class party members gathered ... to discuss the party's plight." ${ }^{44}$ While Murphy, a noted University of Queensland labour historian, had not participated in this meeting, his subsequent inclusion added weight to the reformers' credibility. In addition to his academic credentials, Murphy was a long-time Queensland Central Executive member. In 1972 , he had appeared destined to join the incoming Whitlam government when

41. Peter Beattie, State of the Party Report, 29 June 1980, 3, series OMEQ/62/57, Box 2721, JOL.

42. Labor Party (Queensland) Membership Committee Minutes, 16 May 1983, series OMEQ/62/57, Box 2676, JOL.

43. Peter Beattie, Labor (Queensland) State Secretary's Report to State Council, 13 April 1985, series 3163, Box 4733, JOL; Peter Beattie, Labor (Queensland) State Secretary's Report to State Council, 6-8 August 1988, 21, 23, series 27249, Box 15682, JOL; Lindsay Jones, Labor (Queensland) Assistant Secretary's Report to State Council, 28 November 1992, 5-6, series 27249, Box 15682, JOL; Mile Kaiser, Labor (Queensland) State Secretary's Report to State Conference, 7-9 June 1997, 10, series 27249, Box 15685, JOL.

44. Adrian McGregor, "Labor Reformers in Queensland," National Times, 27 March - 1 April 1978, 29, Beattie, In the Arena, 14-15. 
he was pre-selected for Petrie, one of three Brisbane electorates that Labor expected to win, the others being Lilley and Griffith. In the end, only Lilley was secured, and this by 35 votes. ${ }^{45}$ As Murphy was no doubt aware, Labor's federal office attributed these setbacks to Queensland Labor's determination to run its own "parochial" campaign. The Branch's subsequent lack-lustre electoral performances appear to have confirmed Murphy's view that the Trades Hall leadership was irredeemable. In addressing the Bardon meeting, therefore, Murphy declared that Labor could only "win elections" if its "own organisation" was "representative." To achieve this Murphy and Beattie recommended that branch members should elect 40 per cent of the positions to State Conferences, where delegates would select a State Council and an Administrative Committee (the remainder would stay union-appointed). To allow for dissident opinion the proportional representation of factions was advocated, a reform implemented in Victoria eight years before. ${ }^{46}$

While circumstances changed in ensuing decades, Queensland in 1978 was illsuited to a challenge that drew its strength primarily from the professional middle class. Such people may have made up a goodly part of Labor's Brisbane membership, but the 1976 Census revealed that, state wide, only five per cent of Queenslanders aged 15 years or more were tertiary educated, significantly below the national average ( 7.3 per cent). As Table 4 indicates, the situation changed considerably over the next 20 years. Even in 1996, however, the tertiary educated made up a smaller share of the relevant Queensland population than they did in Australia as a whole. Only in Brisbane City, where 21.9 per cent of those aged over 15 boasted a tertiary education in 1996, were the figures well above the national average. ${ }^{47}$

Table 4: Percentage of Queensland, Brisbane City and Australian Population Aged 15 Years and Over with Tertiary Qualifications, 1976-96*

\begin{tabular}{|l|c|c|c|}
\hline & $\mathbf{1 9 7 6}$ & $\mathbf{1 9 8 6}$ & $\mathbf{1 9 9 6}$ \\
\hline Queensland & $5.0 \%$ & $7.3 \%$ & $14.0 \%$ \\
\hline Brisbane City & $\mathrm{NA}$ & $10.8 \%$ & $21.9 \%$ \\
\hline Australia & $7.3 \%$ & $8.6 \%$ & $16.4 \%$ \\
\hline
\end{tabular}

* Degrees, Diplomas and Associate Diplomas

Source: ABS, Commonwealth Census, 1976, 1986 and 1996, accessed September 2013, http://www. abs.gov.au/websitedbs/censushome.nsf/home/historicaldata?opendocument\&navpos $=280$

Trades Hall responded badly to the Reform Group's establishment. Pamphlets from the Old Guard (as machine supporters were called) denounced reformers as "grubs" and "middle-class academics." ${ }^{48}$ The Reform Group, however, initially lacked the support necessary to pose a real threat to Trades Hall. In consequence, when promised a consideration of its proposals the Reform Group meekly dissolved

45. Malcolm Mackerras, "The Swing: Variability and Uniformity," in Mayer, Labor to Power, 234 41; Blewett, "Labor 1968-72," 12.

46. Labor Reform Group, Case for Reform (Brisbane: Labor Reform Group, 1978), 7, 10-11.

47. Calculated from ABS, Census: Historical Data, 1976, 1986 and 1996, accessed September 2013, http:/ /www.abs.gov.au/websitedbs/censushome.nsf/home/ historicaldata?opendocument\&navpos $=280$.

48. Loyal Labor Members, "Expel these Grubs: They are Traitors to the Labor Cause," Brisbane 1978, Denis Murphy Collection (hereafter DMC), Fryer Library, Brisbane; Bob Hendricks, Letter to ALP Members, 22 April 1978, series OMEQ/62/57, Box 2721, JOL. 
itself. Reform prospects were also dimmed by the AWU's re-affiliation during 1978. Although the AWU supported a rival industrial peak council to Trades Hall (the Combined Unions Industrial Committee), the AWU's then State Secretary, Edgar Williams, shared with his historic rivals a dislike of middle-class reformers, subsequently denouncing the Reform Group as "fleas." ${ }^{49}$

In mid-1978 the Reform Group found itself in the same situation that the Victorian "Participants" had been in a decade earlier - powerless in the face of an entrenched opposition. As was the case in Victoria, their only hope lay in federal intervention. And, as with the case in Victoria, they were favoured by a federal leader dissatisfied with the state's electoral performance. Whereas Whitlam had been instrumental in the ousting of the entrenched Victorian regime in 1970, so it was that Bill Hayden instigated the call for intervention in Queensland's affairs in June 1978 after an attack on his leadership by Old Guard powerbroker, Neal Kane. Hayden's actions had two immediate results. First, the Reform Group was "revived," joining Hayden in calling for federal intervention. ${ }^{50}$ Secondly, the reformers split into competing factions. While Beattie claims that factionalism only occurred after 1980, the inaugural newsletter of Centre Caucus (Beattie's faction) states that it was formed in September 1978. Among its foundation members were Beattie, Madeleine McPherson and Rob Whiddon. ${ }^{51}$ From the outset it was countered by the Socialist Left, which formed a Queensland wing in July 1978.52 Paradoxically, this faction's national strength lay with the Victorian Bill Hartley-led group that had earlier opposed intervention in that state. ${ }^{53}$ Unlike Centre Caucus, whose industrial base was initially restricted to Beattie's Railway Station Officers Association (which he led from 1978 to 1981), the Socialist Left's supporters included the Metal Workers Union, the Building Workers Industrial Union (BWIU) and the Australian Telecommunications Employees Association (ATEA). While Senator George Georges was the faction's best known member, its main power-broker was ATEA President, Ian McLean.

When in September 1978 the Federal Executive announced a restructuring of Queensland Labor the reformers suffered disappointment. While branch members now elected 40 per cent of conference delegates, proportional representation of factions was refused. In consequence, the Old Guard retained control through its union bloc vote. However, on 1 March 1980 the Federal Executive intervened again, sacking state office bearers and installing an Interim Administrative Committee. Parliamentarian Tom Burns was made President. Murphy became Vice-President. Proportional representation of the Queensland factions was conceded. ${ }^{54}$ Unlike their Victorian counterparts, however, the Queensland Old Guard refused to go quietly, denouncing federal intervention as illegal from Labor's Breakfast Creek headquarters. The public was thus presented with a state-registered party controlled by the Old Guard and a federally-recognised Branch installed in "temporary offices" in Charlotte Street. This situation prevailed for the next two years, curtailing popular enthusiasm for either side. As Table 3 indicates, in every year between 1980 and 1982

49. Australian, 17 January 1980, 2.

50. Peter Beattie, News Release: Reform Group, 25 July 1978, series OMEQ/62/57, Box 2721, JOL.

51. Beattie, Arena, 49; Centre Catucus Netusletter 1, no. 1 (1979): 1.

52. Socialist Challenge, October 1978, 1

53. Strangio, "Closing the Split," 355.

54. Denis Murphy, ALP: State of Queensland, Administrative Committee Circular, 26 February 1981 series OMEQ/62/57, Box 2721, JOL. 


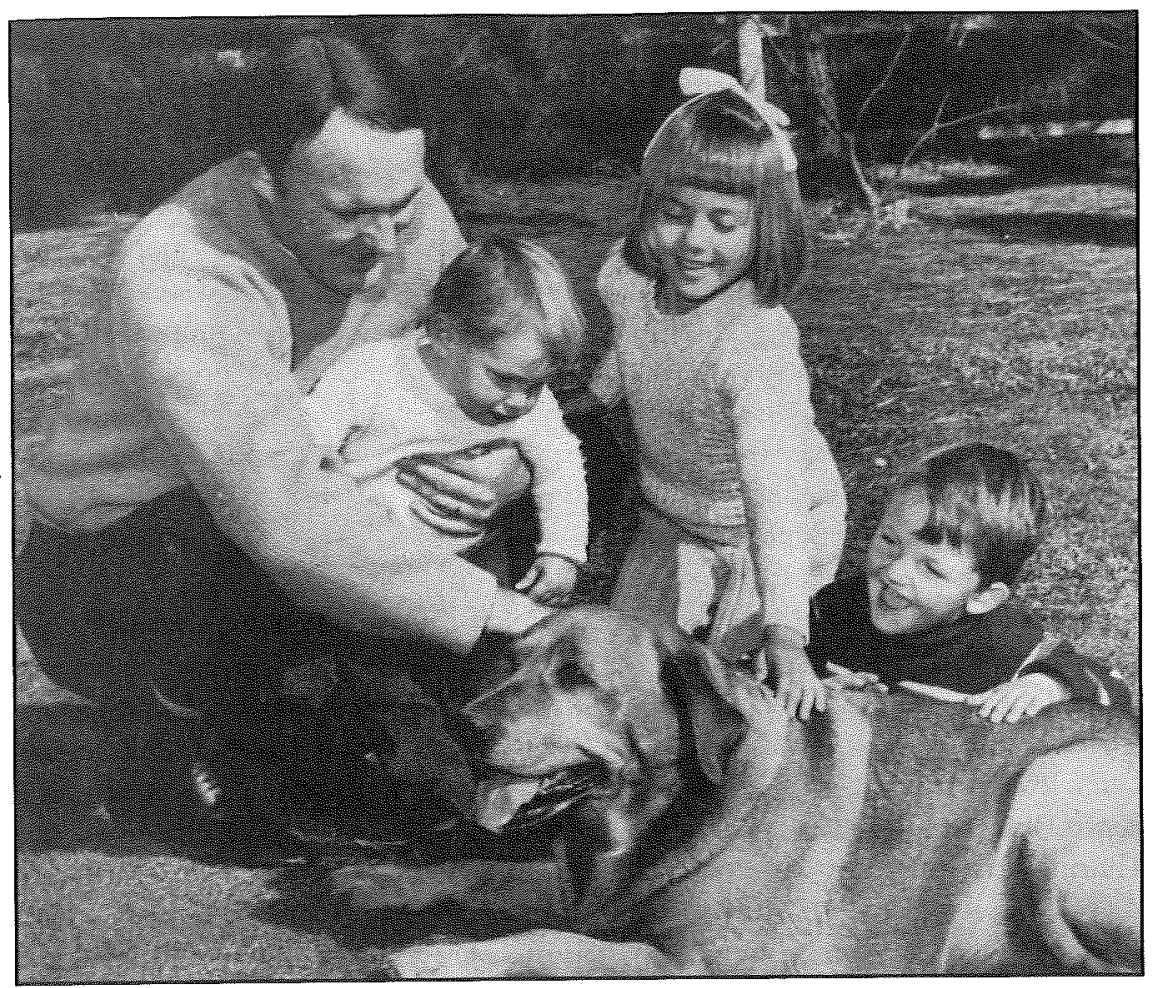

Figure 3: Dr Denis Murphy and Family

Campaign Photo for Federal Electorate of Petrie, 1972

Courtesy: Dr Denis Murphy Collection, Fryer Library, University of Queensland

the party membership was less than it had been in 1976. Not until 1983, in the wake of the Old Guard's re-affiliation, was the 1976 level surpassed.

Although the new administration was supported by a significant union bloc, most were Socialist Left affiliates. These forces shared the Old Guard view that the union vote in internal Labor ballots should not be diminished, condemning the Federal Executive's decision to end the practice of affiliated unionists voting in pre-selections as "a classic case of throwing the baby out with the bathwater." 55 This view contrasted with the opinion of Centre Caucus, whose June 1980 newsletter supported such reforms. This same newsletter also questioned the value of Labor's existing "union connection," noting that it was "basically with ... a numerically declining section of the Australian workforce. ${ }^{\prime 56}$ Such differences were soon manifest in political division within the new administration, leading to the resignation of Burns as President in April 1980 and his replacement by Murphy. ${ }^{57}$ The Left's McLean was made Vice-President. As President, Murphy expressed concern with what he called the "Mad Group of the Socialist Left" around Georges..$^{58}$ While Fitzgerald

\footnotetext{
55. Socialist Left, "What Now?" 1.

56. Centre Caucus, Centre Caucus Newsletter, June 1980, OMEQ/62/57, Box 2695, JOL, 2-4.

57. Labor Party (Queensland) Administrative Committee Minutes, 18 March 1980, series 2657, Terry Hampson File, JOL.

58. Denis Murphy, ALP State Secretaryship: Confidential Paper, 31 August 1981, 4-5, Box 2, DMC.
} 
and Thornton state that Murphy gave only "tacit" support to the Centre faction, 59 his private correspondence contradicts this. Murphy records that he and Hayden "converted" Beattie's Centre Caucus into a nationally-aligned Centre-Left faction. But Murphy still worried. "Beattie," he wrote, was "as devious as McLean." He was "too friendly" with "the media. ${ }^{\prime \prime 0}$ Nevertheless, Murphy supported him and in September 1981 Beattie defeated McLean to become State Secretary. The reformers' plight, however, remained grim. Regional recruitment campaigns had limited success. After a tour of south-west Queensland, Madeleine McPherson and Kev Hooper reported "belligerent opposition at Charleville, in the person of the branch president, AWU organiser Billy Ludwick (sic) ... Throughout the area the heavy-handed influence of the AWU through Billy Ludwick is being felt." ${ }^{\prime 61}$ Despondent, in 1981 Murphy confided to John Button that "we have to wrap up the whole Queensland problem" as by "August or early September we will run out of money." ${ }^{\prime 2}$ The Old Guard was subsequently readmitted in March 1982.

For Murphy, reunification created new problems. Writing in 1991, Swan estimated that following reunification Murphy's Centre-Left faction commanded only ten per cent of the internal vote. The other factions - Old Guard, Socialist Left and AWU - each controlled around 30 per cent. ${ }^{63}$ To counter this, on 6 July 1982 the CentreLeft's leaders secretly concluded a deal with the AWU, now under Errol Hodder's control, becoming part of a new faction, Centre Majority. ${ }^{64}$ Although Fitzgerald and Thornton clear Murphy of involvement, the documentary record again contradicts. As early as August 1981, Murphy was writing to Hayden to advocate a deal with Hodder "as his ideas on Labor getting into power are not very different from ours." ${ }^{\prime 65}$ Moreover, a Centre Majority pamphlet listed its "most prominent members" as Bill Hayden, Denis Murphy, Errol Hodder and Peter Beattie. ${ }^{66}$ While this alliance temporarily protected Murphy and Beattie it also effectively placed control of Queensland Labor in the hands of secretive factions, of which the Centre Majority/ AWU grouping was the most important. Increasingly, ideology was cast aside in a constantly shifting factional mosaic. At the June 1984 State Conference the Socialist Left and Old Guard joined together in what their factional foes called an "unholy alliance." With Murphy having passed away, the Socialist Left's McLean gained the Presidency in an atmosphere described as "poisonous." ${ }^{16}$ Then, in 1986, an even more "unholy alliance" emerged, this time between the Socialist Left and the AWU, the latter having by then broken with Beattie and the rump of the old Centre-Left faction. The Socialist Left's Terry Hampson was promoted to Assistant Secretary. Then, in July 1988, Beattie was forced out of the Secretaryship, obtaining refuge by winning pre-selection for the state seat of Brisbane Central. Hampson took his job. Swan, an AWU loyalist, became Assistant Secretary.

59. Fitzgerald and Thornton, Labor in Queensland, 318.

60. Murphy, Secretaryship, 2, 5.

61. Madeleine McPherson and Kev Hooper, Report on the Tour of South West Queensland, March 1980, series 2657, Terry Hampson File, JOL.

62. Denis Murphy, Correspondence to John Button, 19 August 1981, Box 2, DMC.

63. Swan, "Labor Party," 100-1.

64. Denis Murphy, Centre Majority Faction Meeting, 6 July 1982, Box 4, DMC.

65. Fitzgerald and Thornton, Labor in Queensiand, 318; Denis Murphy, Correspondence to Bill Hayden, 20 August 1981, Box 2, DMC.

66. Centre Majority, "What is Centre Majority?," Brisbane 1984, series 2657, Terry Hampson File, JOL.

67. Australian, 27 June 1984, 1. 


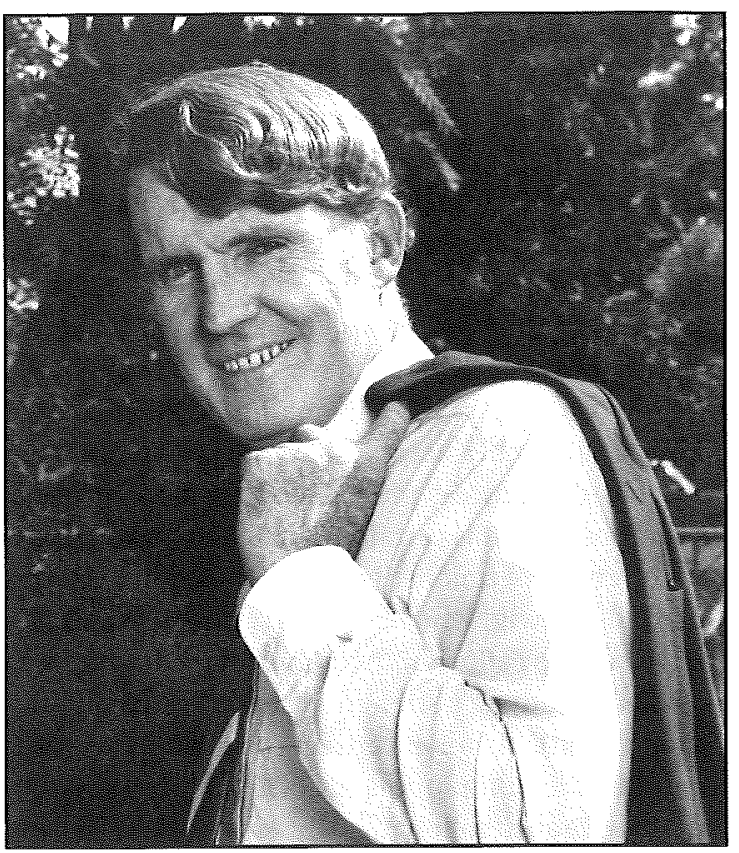

Figure 4: Dr Denis Murphy, 1983

Labour historian, Reform Group founder, Labor Party State President, 1980-84; Member of the Queensland Legislative Assembly, 1983-84

Courtesy: Dr Denis Murphy Collection, Fryer Library, University of Queensland

What had this power struggle achieved? Organisationally, the gains appeared modest. From a low of 6,171 in 1980, a membership peak of 8,806 was obtained in 1984, before falling back to 6,367 in 1989 - more than 500 below the 1976 level (see Table 3). If membership regressed after 1985, Queensland Labor was nevertheless a transformed party - "modern Queensland Labor" had emerged from the defeated ruins of "Old Labour." The most obvious change was in its leadership. Since 1981, every Secretary except for Terry Hampson - Peter Beattie, 1981-88; Wayne Swan, 1991-93; Mike Kaiser, 1993-2000; Cameron Milner, 2000-03; Milton Dick, 2003-08; Anthony Chisholm, 2008 onwards - has boasted a degree. By 1989, moreover, the tertiary-educated were found in all factions and, increasingly, in the parliamentary caucus. Middle-class reformers and Trades Hall learned to live with each other, effectively becoming an "amalgam." The adoption of affirmative action policies in 1982 also made Labor more attractive to women. ${ }^{68}$ Subsequently, female members were found in increasing number in caucus and in party administrative positions. Women also assumed the mantle of behind-the-scenes power-brokers. The greatest number of these was found in the Socialist Left, where Anne Warner, Cath Rafferty, Di Fingleton, Billy Watts and Sue Yarrow and, later, Anna Bligh were prominent. But women were also to the fore in Right-leaning factions. Among the leadership group of Centre Caucus in the early 1980s were Madeleine McPherson (a faction

68. Beattie, Labor (Queensland) State Secretary's Report to State Council, 13 April 1985. 
founder), Deidre Swan and Gaylene Harrison. ${ }^{69}$ Further rightward, Jackie Byrne served as Convenor of Centre Majority (AWU) in the mid-1980s. ${ }^{70}$

At a broader level, the post-1980 reforms did end direct union control. While affiliated unions were still allocated 60 per cent of the internal vote, after 1980 there was no equivalent of the Trades Hall Affiliated Unions Committee wielding power over policy and candidate selection. Queensland unions were, moreover, a declining force. By 1990, only 38.4 per cent of the state workforce was unionised two percentage points less than the comparable national figure. Union influence was also weakened by being dissipated across competing blocs (Social Left, Old Guard and Centre Majority / AWU). This made the 40 per cent branch vote all important. The key to factional success therefore lay in the marrying of union and branch support. As this process progressed, the factions became increasingly heterogeneous in composition. It is certainly a mistake to equate any of the factions with a single union or group of unions. This is best seen in the case of the powerful AWU faction under Bill Ludwig, who became AWU State Secretary in 1988. Unlike earlier AWU oligarchs such as Fallon, Ludwig could not rely simply on his own union to deliver power. Instead, Ludwig's strength rested on three pillars - the AWU itself (the largest affiliated union), his alliance with other moderate unions such as the Shop, Distributive and Allied Employees Association (the second largest affiliated union) and a substantial branch following. Unlike the AWU of yesteryear, much of the latter was found in Brisbane where, as the Shepherdson Inquiry into electoral fraud revealed, the faction found ready recruits amongst ambitious university students and recent graduates. ${ }^{71}$ Indeed, in terms of social composition the AWU faction was indistinguishable from the other factions. Except for Ludwig himself, none of the key figures in the AWU faction in the late 1980s and early 1990s had progressed through the union's ranks. Most, including John Black, Wayne Swan and Mike Kaiser, boasted research qualifications. Even with such an alliance of forces, Ludwig and the AWU faction were, as Kaiser testified in 2001, unable to exert power unilaterally, requiring instead the assent of at least one other faction..$^{72}$ In office, the AWU faction did little to oppose policies that cost unionised jobs (including those of AWU members) through redundancies and asset sales. While there had, perhaps, long been a gulf between the interests of AWU members and their officials, during the 1990s a gap also emerged between the union and the faction that bore its name.

As no one faction held a majority, each manoeuvred furiously to bolster its branch numbers. "Factionalism," so the North Cairns branch advised in 1986, "has never been so rife and so damaging. ${ }^{\prime \prime 3}$ As subsequent testimony to the Shepherdson Inquiry revealed, by this date the factions were engaged in falsifying electoral enrolments on a significant scale in order to boost their numbers. In such machinations, the AWU benefited much from the activities of David Barbagallo, a senior systems officer with Australia Post's computer branch. A future Principal Private Secretary to Wayne Goss, Barbagello later justified his faction's proclivities by observing, "we were attempting

69. Rob Whiddon, Urgent Notice to Centre Caucus Members, 4 February 1980, series OMEQ/62/57, Box 2695, JOL.

70. Jackie Byrne, "Centre Majority: Power \& Principle," June 1984, series 2657, Terry Hampson File, JOL.

71. Criminal Justice Commission (CIC), The Shepherdson Inquiry: An Imvestigation into Electoral Fraud (Brisbane: CJC, 2001), 100-14.

72. Cited, CJC, The Shepherdson Inquiry, 23.

73. Labor Party (North Cairns), Resolution to State Council, June 1986, series 3290, Box 4743, JOL. 
to combat a scenario where we believed the left was [also] stacking." ${ }^{74}$ Such strife was a new phenomenon. As Sue Yarrow and Dick Williams (Labor's current State Secretary) have recorded, prior to 1978 there "were no formalised factions. ${ }^{175}$ This changed with federal intervention in 1980, when "proportional representation" of factions was introduced. Whereas previously members were rendered powerless by Trades Hall control, it was now factional powerbrokers who made all the key decisions. When, for example, the number of Branch organisers was increased to three in 1987, proportional representation meant that the choice of who was successful devolved to the three factions (Old Guard, AWU / Centre Majority, Socialist Left), each of whom put a candidate forth. There was no open contest. ${ }^{76}$ There is little doubt that such circumstances were behind the decline in membership which occurred during the late 1980s, which saw the number of faithful fall from 8,086 in 1984 to 6,367 in 1989 (see Table 3).

While the factional arrangements of the 1980s concentrated power in the hands of a few, they did bring to the fore a generation of Labor leaders who boasted university, rather than union, pedigrees (Wayne Goss, Wayne Swan, Peter Beattie, Anna Bligh). Under Murphy and Beattie, moreover, advocacy of socialism was abandoned in favour of policies emphasising education, the environment and business engagement. Business leaders were, Beattie notes, "wined and dined."77 Party polling, conducted in 1986, showed the fruits of this. The most pro-Labor demographic, the polling revealed, was now "the tertiary educated and the top income earners. ${ }^{\prime 78}$ The problem was that Labor then ossified around these factional arrangements. Many of those who came to the fore in the 1980s - Swan, Beattie, Ludwig and, at decade's end, Kevin Rudd - were still seminal Labor figures more than two decades later. New faces and social forces found progress within Labor's factional hierarchy a difficult proposition, thereby hindering the party's capacity to adapt to ongoing demographic and social change.

\section{Modern Queensland Labor Ascendant, 1989-96}

In 1988-89, fortune again smiled on Labor. Following the Coalition rupture in 1983 the conservative mantle effectively rested on the Nationals, whose image was then tarnished by the Fitzgerald corruption inquiry (1987-89). At the 1989 election the Nationals' vote collapsed. While Labor secured only half the primary vote, its Greater Brisbane success delivered it a decisive victory (see Table 2). For the next 23 years, Labor's success in Brisbane City in particular laid the foundation for a series of electoral victories. There is no doubt that had Labor remained a party of the blue-collar working class the winning of this metropolitan base would have eluded it as, by 1996, professionals and associate professionals represented

74. David Barbagallo, "Testimony to the Shepherdson Inquiry," Shepherdson Inquiry: Redacted Transcripts of Mike Kaiser, Lee Bermingham, Warwick Powell and David Barbagallo (Brisbane: Crime and Misconduct Commission, 2001), 3052, 3044.

75. Sue Yarrow, "Top Dog to Old Hat: Jack Egerton and the Trades Hall Group, 1957 to 1980 ," Queensland Journal of Labour History, no. 16 (2013): 30; Howard Guille and Ross Gwyther, "Interview with Dick Williams: President of the Queensland Branch of the ALP and former Secretary of the ETU," Queensland Joumal of Labour History, no. 16 (2013): 38.

76. John Campbell, Circular to All Socialist Left Members, 12 January 1987, series OMEQ / 72, JOL.

77. Beattie, Arena, 36-44.

78. ANOP Research, Four Old Marginal Seats (Sydney: ANOP, 1986), 3. 


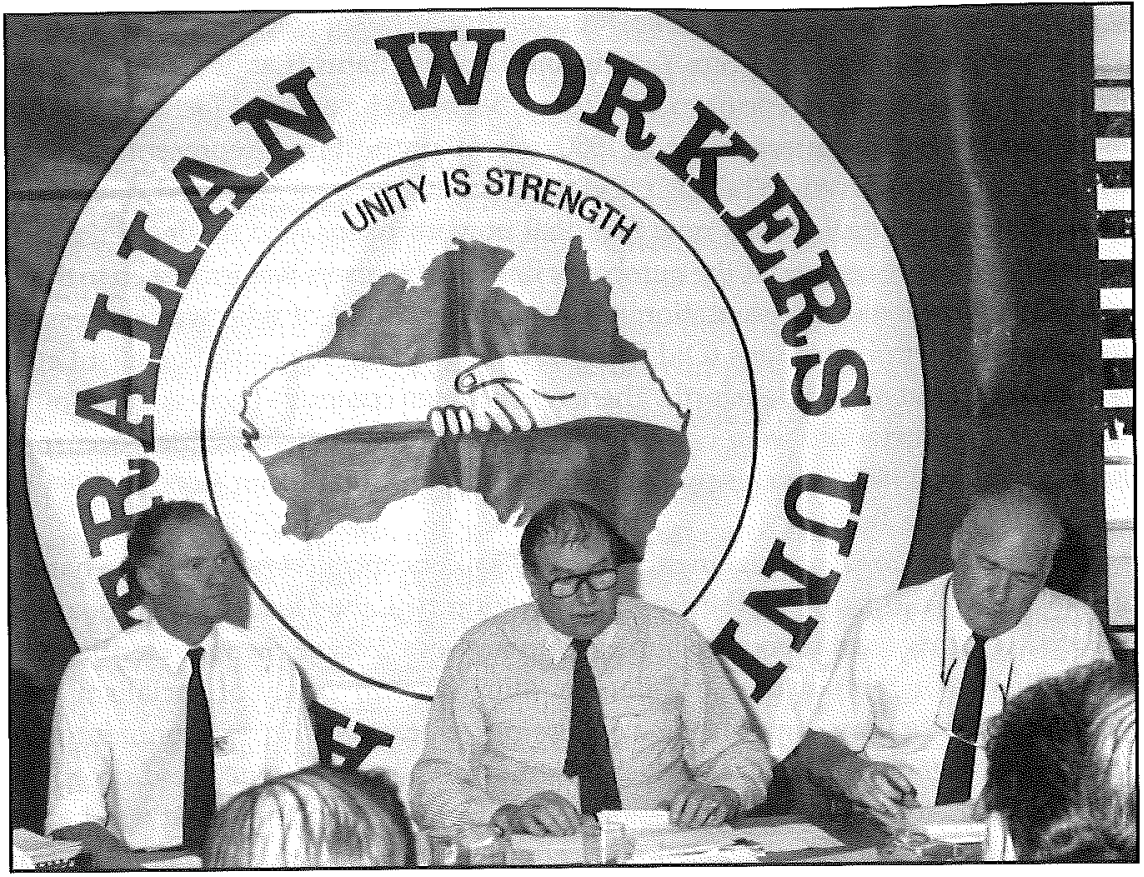

Figure 5: Wayne Goss (left) and Bill Ludwig (centre) at an Australian Workers Union Meeting in Barcaldine, 1991

Goss was Queensland Premier (1989-96), owing his accession as parliamentary leader to the support of the AWU faction. Ludwig was the AWU's Queensland Secretary (1988-2013) and titular head of the powerful AWU faction within the Labor Party

Courtesy: State Library of Queensland, neg. no. 191557

34.4 per cent of Brisbane City's workforce. ${ }^{79}$ The elevation of Wayne Goss, a university-trained lawyer, added to Labor's City appeal. Goss's ascendancy, though, was AWU orchestrated. A factional newsletter, circulated during 1984, indicated that it was peeved by arrangements that protected "sitting Old Guard members" in parliament. ${ }^{80}$ Breaking the Old Guard stranglehold required, however, the removal of parliamentary leader, Nev Warburton. This was flagged in September 1987 at Labor's Political Steering Committee, where Bill Ludwig stated that only Goss had the needed "qualities of leadership." ${ }^{81}$ Warburton stood aside in March 1988.

Writing in mid-1988, Fitzgerald and Thornton concluded that Queensland Labor was "the epitome of destructive factionalism." ${ }^{82}$ Subsequently, however, this judgement has been cast aside. Goss's election as leader, Swan declares, produced a "restoration of party unity." "Thereafter," he adds, "the Queensland branch ... resolved difficult internal party problems maturely." ${ }^{183}$ John Wanna similarly

79. ABS, Census of Population and Housing: Selected Family and Labour Force Characteristics, Australia, 1996, no. 2017.0 (1998): 37, accessed September 2013, http:/ / www.ausstats.abs.gov.au / ausstats / subscriber.nsf/0/CA25687100069892CA2568890026FEBE/\$File/20170_1996.pdf.

80. Centre Majority, Centre Majority News Circular, c. January 1984, series 2657, Terry Hampson File, JOL, 4.

81. Labor (Queensland) Political Strategy Committee Minutes, 12 September 1987, series 3290, Box 4750, JOL.

82. Fitzgerald and Thornton, Labor in Queensland, 357

83. Swan, "Labor Party," 99. 
concludes that under Goss the party moved from "oligarchical" rule to "more inclusive factional arrangements. ${ }^{184}$ Such conclusions are fanciful.

Following the implementation of proportional representation of factions the Queensland party degenerated into increasingly dubious conduct involving not only internal ballot rigging on a grand scale but actual criminality. The exposure of Labor's workings began on 11 August 2000 when an unfortunate AWU operative, Karen Ehrmann, was sentenced to three years' imprisonment for falsified electoral enrolments. Ehrmann, whose conviction was preceded by that of three other AWU underlings, testified that she was "only a bit player in a well-known scheme." ${ }^{15} \mathrm{~A}$ subsequent Criminal Justice Commission investigation, the Shepherdson Inquiry, revealed systematic ballot rorting by at least two of Labor's three factions (AWU and Old Guard) during the period 1986 to 1996, ie the years contemporaneous with the ascendancy of "modern Labor" in Queensland and the emergence of a raft of subsequently prominent political figures. The most common practice was that of falsely enrolling large numbers of people, with or (less commonly) without their knowledge, so that their party ballots could be collected from either postal boxes or "safe houses" and filled in by factional loyalists. Among those who admitted impropriety to Shepherdson, or who were subject to adverse findings, were David Barbagallo (Principal Private Secretary to Wayne Goss, 1992-96), Mike Kaiser (Queensland Secretary, 1993-2000), Jim Elder (Deputy Premier, 1998-2001), Lee Bermingham (Queensland organiser, 1993-97) and John Budd (Queensland Party Treasurer, Member for Redlands 1992-95 and husband of Joan Budd, Labor's returning officer). In Shepherdson's opinion, the behaviour detected within Labor was such that it "subverted the electoral process." 86

Under Goss Labor, jobs lured recruits. Shaun Rohrlach advised Shepherdson that, having won a job "in Wayne Goss's office" through his factional links, he then signed false enrolment declarations when told that "you need to demonstrate your loyalty ... we've supported you with getting employment." Another member, Rodney Mugford, testified that "it was a regular thing for there to be promises that you would be looked after in relation to jobs if you did what you were told." ${ }^{87}$ The Inquiry was also told that Jackie Byrne, Deputy-Director of the Office of the Cabinet and former AWU faction Convenor (and Kevin Rudd's deputy), was central to this ${ }^{88}$ Shepherdson's Inquiry also revealed how, in the case of at least the AWU faction, "runners" at State Conferences collected "the ballot papers of all of the people who they considered to be aligned." They were then taken away to be filled in. Testimony also pointed to an AWU faction "slush fund" wherein money raised through business lunches paid the dues of "phantom members." 89 In such circumstances it is hardly a matter of wonder that many lost not only any sense of ideological purpose but even their moral compass. As Ehrmann observed with regard to her own criminality,

84. John Wanna, "Queensland: Consociational Factionalism or Ignoble Cabal," in The Machine: Labor Confronts the Future, ed. John Warnhurst and Andrew Parkin (Sydney: Allen \& Unwin, 2000), 130.

85. Cited, CIC, Shepherdson Inquiry, 1; Queensland Court of Appeal, Queen v Karen Ehrmam, case 253 of 2000, 21 February 2001, accessed September 2013, http:/ / archive.sclqld.org.au/ qjudgment/2001/QCA01-050.pdf.

86. CJC, Shepherdson Inquiry, 21, viv-xviii, 170

87. Cited, CJC, Shepherdson Inquiry, 108-9.

88. CJC, Shepherdson Inquiry, 112.

89. CJC, Shepherdson Inquiry, 33. 
"other people were doing similar things. It wasn't something that I was doing in isolation or that I had dreamed up myself.,"90

What is the significance of such behaviour, wherein Labor was controlled by a small group of powerbrokers and apparatchiks? First and foremost, it glaringly exposed the underlying dynamics of "modern Labor," a party within which it was impossible for anyone to progress through the ranks without becoming, to a greater or lesser degree, a creature of the factions. Members were left with three choices: leave, become marginalised or join a faction. Even if they took the latter option, however, there were few meaningful roles. For, in another defining characteristic of "modern Labor," money was substituted for members - money used for research, polling, marketing and the general funding of a professionalised campaign machine. Following the sale of $4 \mathrm{KQ}$ and its Newstead offices in 1986, Labor's portfolio prospered under Ian Brusasco, the Chair of Labor Holdings. In 1988, Labor Holdings' subsidy to the organisational wing was $\$ 1,027,000 .{ }^{11}$ A decade later the subsidy from Labor Holdings and Labor Resources was $\$ 3.2$ million. This amounted to 42.8 per cent of its income, which totalled $\$ 7.7$ million. Another $\$ 1.7$ million came from donations, most from business. A further $\$ 1.7$ was received from Labor's federal office, this being Queensland's share of Commonwealth electoral funding. By comparison, union affiliation fees amounted to only 14.1 per cent of receipts ( $\$ 1.1$ million). Little money was obtained from members. ${ }^{92}$ In 1995 , State Council delegates were told that "most" branches had not paid their annual registration fee. ${ }^{93}$ Rather than it being a case of members providing financial support for Labor the reverse occurred when, in 1996, the party began paying, to branches, the dues of newly recruited members. Thus, in October 1996, the Left's Kurilpa Branch received \$182 for signing up seven members. The adjacent AWU-dominated Chardon's Corner Branch received $\$ 847$ for recording an additional 40 members. ${ }^{94}$

The factional system that characterised "modern Queensland Labor" also meant that what members there were tended to be concentrated in places where numbers could be fostered by parliamentarians and paid apparatchiks. This reinforced the organic transformation of Labor into a party whose membership was increasingly concentrated in Brisbane City. In 1987, 3,861 of Queensland Labor's 7,578 members were in Brisbane-based federal electorates. This was 51 per cent of the whole. After slumping to 6,367 in 1989, membership grew once Labor was in office. Most gains occurred in Brisbane, which by 1992 had 4,317 of the party's 7,937 members (59.6 per cent of the total). ${ }^{95}$ Much of this increase must be attributed to those who found employment in Ministerial Departments or in Rudd's Office of the Cabinet. Such people were encouraged not only to join themselves but, as Shepherdson was told, "to get people you knew," such as "family members," to join as well.96 Outside the metropolis, Labor's greatest strength was in North Queensland, where

90. Cited CJC, Shepherdson Inquiry, 30.

91. Labor (Queensland) Companies Board Minutes, 29 February 1988, series 3290, Box 4746, JOL

92. Queensland Labor Party Retum, 1998-99 (Canberra: Australian Electoral Commission, 1999).

93. John Budd, Treasurer's Report to Labor (Queensland) State Council, 25 March 1995, series 27249, Box 5688, JOL.

94. Mike Kaiser, Correspondence to Kurilpa Branch, 1 October 1996; Mike Kaiser, Correspondence to Chardons Corner Branch, 1 October 1996, series 27249, Boxes 15695 and 15698, JOL.

95. Beattie, Labor (Queensland) State Secretary's Report to State Council, 6-8 August 1988; Jones, Labor (Queensland) Assistant Secretary's Report to State Council, 28 November 1992.

96. CJC, Shepherdson Inquiry, 29. 
935 members were recorded in $1992 .{ }^{97}$ But here again, factional manipulation was involved; manipulation which ultimately led to the conviction of Ehrmann and her co-conspirators. While these individuals were found guilty of improprieties carried out in 1993, it appears that membership fraud continued well past this date. Writing to Beattie in 1997 (after he assumed the parliamentary leadership) a Townsville member complained that "phantom voters" were still commonplace in internal ballots. ${ }^{98}$

It was not, however, just Labor's internal failings that caused harm. Under Goss, Labor pursued a vigorous policy of corporatisation and public sector redundancy. In part, the 1991-92 recession was behind this. But the pursuit of economic efficiency as a central objective also pointed to a shift in Labor's centre of gravity, demonstrating the inability of Labor's old unionised base to influence policy direction. Regional areas bore the brunt of job losses as ports, power generation and Queensland Rail were all corporatised. The railways suffered particularly heavy losses as sectoral employment fell by 6,000 to 15,650 between 1990 and 1995. The Minister, Ken Haywood, warned railway staff in May 1995 that job losses "will necessarily continue for several years. ${ }^{\prime 99}$ All of this was a shock to an electorate accustomed, under both Labor and conservative administrations, to a policy of "agrarian socialism" buttressed by state ownership and largess. Union malcontents leaked stories to the Coalition, which defended state ownership. The Nationals' Bob Katter declared in 1991 that: "Every day that goes by opposition members receive more and more information. The union movement provided most of this." 100

As an internal Queensland Labor inquiry (presided over by Mick Young) acknowledged in 1995, Goss and his Ministers were ineffective in providing an intellectual justification for their policies. ${ }^{101}$ In this they differed much from the Hawke-Keating government of the same era. This would appear no accident as the highly factionalised environment that characterised Queensland Labor after 1980 curtailed serious debate. In consequence, the articulation of a public policy agenda was largely left to a small number of academic mandarins elevated to high office under Goss, most notably Kevin Rudd, Glyn Davis and Peter Coaldrake. On coming to power in 1989, Goss immediately created a Public Sector Management Commission (PSMC) to restructure the public service. Initially overseen by Coaldrake (its Chair), Davis and David Chen, the PSMC undertook wholesale changes with little in the way of consultation. Public sector unions, who had initially welcomed Labor's election, were alienated. By 1991, Laurie Gillespie of the State Services Union proclaimed that Labor had brought about "a rout of the public sector - a destruction of careers; a frustration of endeavour." ${ }^{102}$ As traditional public structures were dismantled, power was concentrated in Rudd's hands. After serving as Goss's Principal Secretary, in mid-1991 he was appointed Director-General of a new Office of the Cabinet through which all essential business passed (command of which passed to Davis in 1994 when Rudd left to contest Griffith). With the business of 51 cabinet meetings and 903 Departmental submissions processed by his office in

97. Jones, Labor (Queensland) Assistant Secretary's Report to State Council, 28 November 1992.

98. Mike Keane, Correspondence to Peter Beattie, 7 October 1997, series 27249, Box 15699, JOL.

99. Queensland Parliamentary Debates (QPD) (26 May 1995): 12104.

100. QPD (11 April 1991): 7134, 7481.

101. Labor Party (Queensland), The Young Inquiry: The ALP Queensland Branch Committee of Inquiry into the 1995 State Election Restults (Brisbane: Labor Party, October 1995), 8-9.

102. Reproduced in, Laurie Gillespie, "Public Sector Reform: Renaissance or Rout?" in Public Sector" Reform Under the First Goss Government, ed. Glyn Davis (Brisbane: Griffith University, 1993), 283. 
its first year, Rudd's staffers constantly besieged other public servants for more information. ${ }^{103}$ In the wake of the 1995 election, Kaiser (Labor's Secretary) conceded that "we lost the public service vote, and I accept that part of the reason for that was the resentment that was built up towards the Office of the Cabinet."104 Such resentment also appears to have alienated many Labor members. By 1995, reported membership was 1,286 less than it had been in 1984 (see Table 3). Within the Labor hierarchy, deep personal animosities developed between Rudd, who joined the Old Guard (Labor Unity) faction to foster his career, and Ludwig. When, after 2010, Rudd sought to regain the Prime Ministership his most implacable opponents were found in the Queensland AWU faction. When caucus restored Rudd to power in June 2013, the faction continued its opposition to the end, its members resigning Ministries rather than serve a restored Rudd.

\section{Social Divides and Queensland Labor Since 1995}

As Queensland's population grew by more than two-thirds in the two decades after 1976, jobs were concentrated in six industries - construction, utilities, retail and wholesale trade, community services (including health and education), finance and property services, and accommodation and recreation. Collectively, these industries increased their share of jobs from 53.1 to 68.5 per cent. This had a number of effects, most detrimental to Labor's prospects. The most obvious effect was a disproportionate increase in the number of employers and self-employed. Whereas 13.8 per cent of the labour force was so engaged in 1976, by 1991 the figure was 19.2 per cent. This trend was most apparent outside Greater Brisbane, where 22.6 per cent were business owners in $1991 .^{105}$

This "new" workforce was found in greatest numbers in the southern coastal districts, where a shortage of paid work fostered self-employment. Such people became, as a visitor to Gympie in Queensland's Wide Bay area observed, part of "a new class of rural poor, displaced from the cities and towns of the south." 106 An analysis of the demographic characteristics of the Wide Bay region - embracing former Labor strongholds such as Bundaberg, Maryborough and Gympie (a town that once returned Andrew Fisher) - certainly reveals a population marked by poverty. In 1996, the Wide Bay boasted 228,586 people. Barely 46 per cent of those aged over 15 years had a job. Half of all households ( 49.7 per cent) received a weekly income of less than $\$ 500$ (the Brisbane City figure was 25.8 per cent). ${ }^{107}$ Initially, this

103. Glyn Davis, "Executive and Policy Co-ordination," in The Goss Government: Promise and Performance of Labor in Queensland, ed. Bron Stevens and John Wanna (Melbourne: Macmillan, 1993), 32-50.

104. "Transcript of Interview with Mike Kaiser, 16 May 1996," in Electoral Wrath: The 1995 Queensland General Election, ed. Andrew Fraser (Brisbane: Griffith University, 1997), 94.

105. ABS, Commonuealth Census of Population and Housing: Characteristics of Population and Duellings in Local Government Areas, Queensland, 1971, no. 2429.0 (1978): 4, accessed September 2013 , http: / / www.ausstats.abs.gov.au/ausstats/free.nsf/0/ABA3DAEA88A4E9D6CA257589000F 0416/\$File/24290_1976_LGA_QLD.pdf; ABS, Commonwealth Census of Population and Housing: Characteristics of Queensiand, 1991, no. 2710.3 (1993): 31, 73, accessed September 2013, http:// www.ausstats.abs.gov.au/ausstats/free.nsf/0/1AD7ACAE3C0CC34BCA2574BE0083393A/\$Fi le/27103 1991_60_Census_Characteristics_of_Queensland,pdf.

106. Nicholas Rothwell, "Hanson's Heartland," Australian, 6-7 July 1998, 22

107. ABS, Commonwealth Censts of Population and Housing: Selected Family and Labour Force Characteristics for Statistical Local Areas, Queensland, 1996, no 2017.3 (1998): 9, 12-13, 30, 34 accessed September 2013, http://www.ausstats.abs.gov.au/Ausstats/subscriber.nsf/0/ CA25687100069892CA256889001FFD8E/SFile/20173_1996.pdf. 
population swelled Labor's vote. In 1989, and again in 1995, Labor won Bundaberg, Maryborough and Hervey Bay. Previously, in 1986, its only coastal success was in Bundaberg. But Labor did little to engage with this population, either through local investment or through branch recruitment. Alienation manifested itself first in a declining Labor vote then, in 1998, through support for Pauline Hanson's One Nation Party. In 1998, One Nation captured two Wide Bay electorates (Maryborough and Hervey Bay) and came close to winning Bundaberg and Gympie. In Gympie, once Fisher's pride, Labor was outpolled by One Nation by 39.2 to 26.1 per cent.

If a divide emerged during the 1990s between Brisbane City with its large professional workforce and the southern coastal districts, another emerged between the City and its metropolitan fringe. Unlike the increasingly tertiary-educated City population, in 1996 only 10.7 per cent of those aged over 15 years in outer metropolitan localities was tertiary-educated in $1996 .{ }^{108}$ In this region, as in the southern coastal districts, Labor's vulnerability was first exposed in the 1995 and, more particularly, the 1998 elections. In 1995, only two of the outer metropolitan electorates were lost, Albert and Redlands. This result, however, disguised wider declines. In Ipswich and Ipswich West, both of which housed many railway workers, Labor's primary vote fell by around 11 per cent. Such declines prepared the way for One Nation. In 1998, the outer metropolitan seats of Ipswich West and Caboolture figured among the Labor losses to the nascent party, the others being Hervey Bay, Maryborough (coastal), Thuringowa and Whitsunday (provincial). But even in the outer metropolitan seats that Labor maintained, One Nation invariably won at least a quarter of the vote. In Ipswich, One Nation won 39.5 per cent. In adjacent Bundamba it gained 34.3 per cent. To the City's immediate south, in Waterford and Logan, One Nation secured 29.3 and 28.6 per cent respectively. In contrast, One Nation's City vote rarely exceeded 15 per cent. ${ }^{109}$

Having alienated diverse constituencies, Labor's primary vote fell from 49 per cent in 1992 to 43 per cent in 1995. Initially, this was enough for a majority of one. However, this buffer disappeared after a court-ordered re-ballot for Townsville-based Mundingburra in February 1996. Following a Liberal win, Rob Borbidge became the head of a minority Coalition government. In the wake of this reversal, Beattie replaced Goss as parliamentary leader. Given past hostility by factional powerbrokers towards Beattie, it is probable that many saw him as a short-term leader whose media skills would restore some lost support. However, at the ensuing 1998 election, with One Nation rampant, Labor's primary vote went backwards, falling to 39 per cent (see Table 2). But, in a quirk of fate, this was enough for Labor to regain office with the support of a rural Independent. For while One Nation, which obtained 22.7 per cent of the vote, took support from Labor it took even more from the Liberals and Nationals, whose combined vote fell to 33 per cent. Central to Labor's victory was its Brisbane City performance, which saw Labor win all but four of the seats on offer (see Table 2). In the ensuing 11 years, this City base was to provide the platform for further victories in 2001, 2004, 2006 and 2009.

108. ABS, Census of Population and Housing: Selected Family and Labour Force Characteristics, Australia, 1996, no. 2017.0 (1998): 37.

109. Parliament of Australia, 1998 Queensland Election, accessed September 2013, http://www.aph. gov.au/About_Parliament/Parliamentary_Departments/Parliamentary_Library/Publications_ Archive/CIB/ cib9899/99CIB02 
Labor's success under Beattie has largely been attributed to his populist image and media skills. ${ }^{1{ }^{10}}$ However, Beattie also benefited from a strongly growing economy. While Beattie made much of "Smart State" investments during his years in office (1998-2007) the real drivers of growth were construction, utilities, and rental and real estate services, all of which experienced average annual growth rates in excess of 5.5 per cent as the population rose from 3.4 to 4.1 million. ${ }^{111}$ This had two wonderful effects. First, swelling stamp duty receipts spared the need for further public sector economies. Second, it placated the small business owners and self-employed who now comprised much of the outer metropolitan and southern coastal populations. When, following Beattie's well-timed political retirement in 2007, the Global Financial Crisis burst the property bubble the government found itself beset again with difficult choices. And, in a further revelation of the impotence of Labor's remnant unionised base, Anna Bligh made similar choices to Goss, selling off government assets including much of the railways. Confronted with a unified opposition in the Liberal-National Party, Labor was evicted from office in March 2012, winning only seven of the Parliament's 89 seats.

If macro-economic factors do much to explain Labor's fluctuating fortunes after 1995, the scale of its 2012 reversal also pointed to a continuing organisational malaise. Although the Shepherdson revelations in 2000 curtailed factional warfare, the features that had characterised Labor under Goss - an atrophied membership and the substitution of money for rank-and-file activism - continued. The inrush of recruits that followed Beattie's election, bringing membership to 7,937, proved another false dawn. While reliable membership figures after 1998 are elusive, seepage of strength is nevertheless evident. In 2004, Queensland Labor reported (perhaps exuberantly) 7,000 faithful. ${ }^{112}$ By September 2012, in the wake of the Bligh government's defeat, only 5,000 were left - the lowest figure recorded in 37 years. ${ }^{113}$

Under Beattie and Bligh, as under Goss, it was money rather than members that sustained Labor. Even here, however, Queensland Labor suffered adversity after 2007. Prior to this date, Queensland Labor's finances burgeoned due to donations from its investment arms, most notably Labor Holdings. As noted earlier, in 1998-99 the receipts from Labor Holdings and Labor Resources were $\$ 3.2$ million, representing 42.8 per cent of the Branch's total income of $\$ 7.7$ million. By $2006-07$ these two entities were providing Queensland Labor with $\$ 8.35$ million. This was exactly two-thirds of all receipts, which then stood at \$12.5 million. In 2010-11, however, Labor Holdings (the only remaining investment entity to provide an income) gave the Branch only $\$ 1.3$ million, representing 16.4 per cent of a much reduced income of $\$ 7.9$ million. ${ }^{14}$ The smaller donation from Labor Holdings reflected a collapse in its financial position. Whereas the company had been virtually debt free in 2002-03 with investment receipts of $\$ 8.5$ million, it had then added to

110. See, for example, Paul Williams, "How Did They Do It? Explaining Queensland Labor's Second Electoral Hegemony," Queensiand Review 18 (2011): 112-33.

111. Queensland Treasury, Annual Economic Report 2009-10 (Brisbane: Queensland Treasury, 2010), 3-16.

112. Dean Jaensch, Peter Brent and Brett Bowen, Australian Political Parties in the Spotlight (Canberra: Australian National University, 2004), 55.

113. Michael McKenna, "Grassroots Abandon ALP," Australian, 28 March 2013, 1, 6.

114. Australian Electoral Commission (AEC), Australian Labor Party State of Queensiand: Disclosure Return 2006-07 (Canberra: Australian Electoral Commission, 2007); AEC, Australian Labor Party State of Queensland: Disclosure Retwrn 2010-11 (Canberra: Australian Electoral Commission, 2011). 
its portfolio by acquiring debt. Initially this paid off. In 2005-06, when debts stood at $\$ 1.8$ million, investment receipts amounted to $\$ 15.4$ million. But by $2011-12$ Labor Holdings was in a dire position with debts of $\$ 11.8$ million (most of it owed to the Commonwealth Bank) and receipts of only $\$ 4.8$ million. ${ }^{115}$ Three things were behind this sharp deterioration, notably soured investments during the Global Financial Crisis, a $\$ 5$ million donation to Kevin Rudd's election campaign in 2007 and the expenditure of $\$ 8.1$ million on Labor's failed state re-election bid in March 2012. ${ }^{116}$ With much of its former nest egg gone, Queensland Labor suddenly found itself reliant on more traditional sources of income. In 2010-11, the largest source of money was once more the union movement, which provided $\$ 2.2$ million. While this circumstance increased union leverage within Labor, union dues nevertheless represented only 27.7 per cent of the Branch's (much reduced) income of $\$ 7.9$ million. Almost as much money came from donations from business and individuals, these amounting to $\$ 2.1$ million (26.7 per cent). ${ }^{117}$ But neither union affiliation fees nor business donations, which one would expect to fall with Labor now out of power in Queensland, were enough to keep the Branch in the manner to which it had grown accustomed. With such financial problems adding to the woes associated with a declining membership, the foundations of modern Labor in Queensland now seem anything but secure.

\section{Conclusion}

In launching the Reform Group in 1978, Denis Murphy noted the oligarchic tendencies of the Trades Hall machine that then ran Labor. But, Murphy continued: "There is nothing new in this. It has been the case since the mid-1920s." ${ }^{118}$ Such comments remind us that oligarchic rule and membership disempowerment are old, not new, Labor phenomena. Nevertheless, this study has argued that "modern Labor" in Queensland is different from "Old Labour" because of the changes that have occurred since 1978. Many changes are self-evident - the substitution of money for members, the professionalisation of the machine and the prevalence of the tertiaryeducated in Labor's leadership. But behind these changes is a more fundamental transformation. Prior to 1980 the Labor Party was clearly a "labour party," ie a party where ultimate control lay unquestionably in union hands. After 1980 and federal intervention, Labor became something different, a faction-controlled party. For in a fulfilment of Michels' theorem that struggles between new and old elites "typically" result in an "amalgam," Queensland Labor was transformed into an organisation wherein an increasingly middle-class membership operated inside the shell of the old "labour party." Direct union influence was diluted by giving branch members 40 per cent of the vote in party ballots (increased to 50 per cent in 2002). Well meaning, this reform had unintended consequences. Under the new rules, no internal grouping could succeed without a strong union vote. But nor could they succeed without a large share of the branch vote. Such circumstances bred factions whose

115. AEC, Labor Holdings Pty Ltd: Associated Entity Disclosure Return 2002-03 (Canberra: Australian Electoral Commission, 2003); AEC, Labor Holdings Pty Ltd: Associated Entity Disclosure Return 200506 (Canberra: Australian Electoral Commission, 2006); AEC, Labor Holdings Pty Ltd: Associated Entity Disclosure Return 2011-12 (Canberra: Australian Electoral Commission, 2012).

116. Michael McKenna, "ALP Eyes Union Cash Bailout," Australim, 3-4 August 2013, 7.

117. AEC, Australian Labor Party State of Queensland: Disclosure Retum 2010-11, 1-7.

118. Murphy, Address, 6. 
success lay in marrying control of a union bloc with branch allegiances, however contrived. Initially this favoured union-based faction leaders such as the Socialist Left's Ian McLean and the AWU's Bill Ludwig. Over time, however, the factions assumed a professional middle-class hue as they increasingly drew membership from among Brisbane's tertiary-educated. And because the faction system worked best with Labor in office, when apparatchiks could be rewarded with jobs, policy was increasingly directed towards the City's growing professional middle class. Between 1989 and 2012 the fruits of this were found in a string of electoral successes. Internally, however, these same trends weakened Labor's union remnant whilst further entrenching the factions. With Queensland Labor awash with money from business investments and donors, the factions also discovered the system worked well with few members, at least while Labor was in government. Despite almost a generation in power, party membership has seldom exceeded the figure which caused Murphy angst in $1976(6,890)$.

If the reforms which Beattie and Murphy initiated in 1978 ended in a factioncontrolled Queensland Branch, the restoration of Kevin Rudd as Prime Minister in mid-2013 witnessed renewed calls for national party reform via membership empowerment and an ending of "union control." However, the transformation of Labor into an organisation with a mass, engaged membership clearly faces immense difficulties. Previously, Cavalier, Dyrenfurth and others have argued that real power within Labor now rests with factions largely composed of university-educated professionals, and that these factions are increasingly self-serving. This study goes further by suggesting that "modern Labor," at its heart, represents an accommodation of two distinct social forces - the old unionised blue-collar working class and an ascendant professional middle class. It is for this reason that the issue of ending "union control" is so fraught for Labor. As Michels observed, in any struggle for power within a political party, rendering "the complete defeat" of one side is always difficult. ${ }^{119}$ If a rule change was to strip the unions of their bloc vote, it is likely they would seek to maintain their ebbing influence by directly enrolling union activists in Labor branches. Even if the unions did suffer "complete defeat," their elimination would probably entrench a trend long apparent in Queensland, the replacement of a "union-controlled party" by a "faction controlled party." In other historical contexts, such stalemates have resulted in Bonapartist solutions, whereby an individual enforces their will through an appeal to the populace. Whatever the attractions of a Bonaparte, however, their ascendancy has always ended in catastrophic defeats on the field of battle. Moreover, as Marx famously observed in "The Eighteenth Brumaire of Louis Bonaparte," once such "personages appear" they tend to do so not once but twice, "the first time as tragedy, the second time as farce." ${ }^{120}$

Bradley Bowden is a labour and business historian employed as a Professor at the Griffith University business school. He is also currently Executive Member and Professional Development Chair of the Management History Division of the American Academy of Management.

$<$ b.bowden@griffith.edu.au>

119. Michels, Political Parties, 52.

120. Karl Marx, "The Eighteen Brumaire of Louis Bonaparte," Collected Works of Karl Marx and Frederick Engels, Volume 1 (Moscow: Foreign Languages Publishing House, 1951), 225. 